ISSN 1678-3921

Journal homepage: www.embrapa.br/pab

For manuscript submission and journal contents, access: www.scielo.br/pab

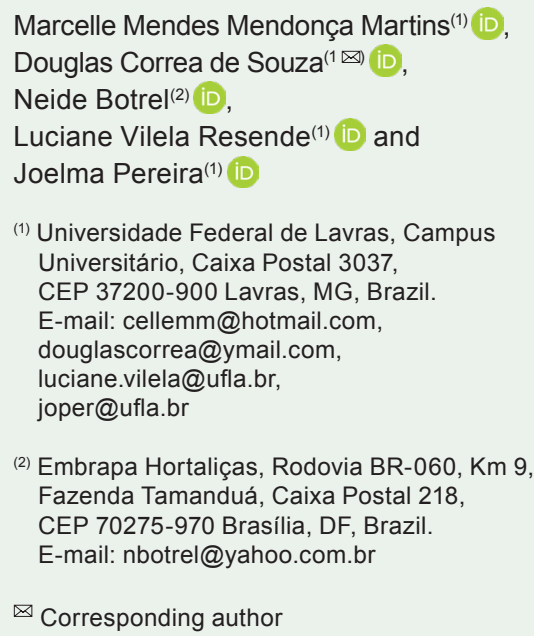

\section{Xanthosoma riedelianum starch for use in the food industry}

\begin{abstract}
The objective of this work was to characterize the starch of Xanthosoma riedelianum, commonly known as "mangarito" in Brazil, and to evaluate its properties for the food industry. The starch was characterized as to its morphology and its thermal and technological properties. Morphology was evaluated by the analysis of granule size distribution, scanning electron microscopy, and X-ray diffraction. The thermal properties were examined by determining the initial, peak, and conclusion gelatinization temperatures, whereas the technological properties were obtained by analyzing viscosity, swelling power, solubility index, paste clarity, and syneresis. Although the extraction of $X$. riedelianum starch showed a low yield, the species is a source of starch with a high sticking temperature, mechanical stirring resistance, tendency to retrograde, and final viscosity. Therefore, this starch is ideal for products that require high viscosity, such as pie fillings, puddings, children's foods, and bakery products, and its paste, which is opaque and viscous, can also be used in the formulation of broths.
\end{abstract}

Index terms: rheological properties, thermal properties, unconventional vegetable.

\section{Amido de Xanthosoma riedelianum para uso na indústria de alimentos}

Resumo - O objetivo deste trabalho foi caracterizar o amido de Xanthosoma riedelianum, comumente conhecido como mangarito no Brasil, e avaliar suas propriedades para a indústria alimentícia. $\mathrm{O}$ amido foi caracterizado quanto à sua morfologia e às suas propriedades térmicas e tecnológicas. A morfologia foi avaliada por meio de análises de distribuição de tamanho dos grânulos, microscopia eletrônica de varredura e difração de raios X. As propriedades térmicas foram examinadas por meio da determinação das temperaturas inicial, de pico e de conclusão de gelatinização, enquanto as propriedades tecnológicas foram obtidas pelas análises de viscosidade, poder de inchamento, solubilidade, claridade da pasta e sinérese. Embora a extração do amido de $X$. riedelianum tenha apresentando baixo rendimento, a espécie é uma fonte de amido com altas temperaturas de empastamento, resistência à agitação mecânica e tendência à retrogradação, bem como elevada viscosidade final. Portanto, o amido é indicado para produtos que requerem elevada viscosidade, como recheios de tortas, pudins, alimentos infantis e produtos de panificação, e sua pasta, que é opaca e viscosa, também pode ser usada na formulação de caldos.

Termos para indexação: propriedades reológicas, propriedades térmicas, hortaliça não convencional. 


\section{Introduction}

Starches have been modified by the food industry through costly processes - chemical, physical, or enzymatic, for example - that alter their typical properties (Lewicka et al., 2015). However, the food sector has been increasing the search for native starches with specific properties, such as a greater resistance to light and strong mechanical stresses, high acidity, and compatibility with the ingredients present during the cooking phase, including acids, sugars, fats, and salts (Waterschoot et al., 2015).

Xanthosoma riedelianum (Schott) Schott, commonly known in Brazil as "mangarito", is an example of a species that stands out nutritionally as a highly energetic

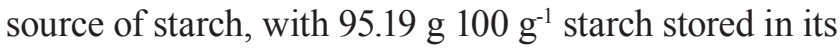
rhizomes (Ávila et al., 2012). The starch from this species

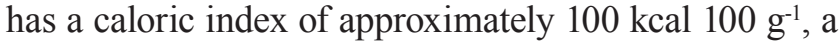
dry matter content between 17 and 20\%, and a protein content from 3.0 to 3.5\% (Ávila et al., 2012; Madeira et al., 2015). Currently, the market for $X$. riedelianum is on the rise due to the growing interest in haute cuisine and to the great potential of the species for family farming, attributed to its rusticity, low production cost, and profitability (Madeira et al., 2015).

Therefore, starch is relevant for Brazilian agribusiness, especially for family farming, showing the importance of the rescue of unconventional species by the market and, consequently, of studies on their production, considering the limited technical information available in the literature about their cultivation (Souza et al., 2018). Incipient studies on $X$. riedelianum should focus on its increased productivity and commercial quality (Madeira et al., 2015).

Research on the technological, physicochemical, and morphological properties of starches from unconventional sources is essential to improve the functionality of these substances and to verify their applicability in the food, pharmaceutical, textile, packaging, and paper industries (Souza et al., 2019; Macena et al., 2020).

The objective of this work was to characterize the starch of Xanthosoma riedelianum, commonly known as "mangarito" in Brazil, and to evaluate its properties for the food industry.

\section{Materials and Methods}

The experiment was conducted at the Department of Food Science of Universidade Federal de Lavras, located in the municipality of Lavras, in the state of Minas Gerais, Brazil. The $X$. riedelianum rhizomes used for starch extraction were supplied by Embrapa Hortaliças (Brasília, DF, Brazil). The experimental design was completely randomized, with three replicates for each analysis.

The starch extraction process followed the recommendations of Daiuto \& Cereda (2003). The material was oven-dried at $45^{\circ} \mathrm{C}$ for 24 hours. The starch extraction yield (EY), expressed in percentage, was calculated by the equation:

$$
\mathrm{EY}=\frac{\text { Starch weight }(\mathrm{g}) \times 100}{\text { Weight of } X . \text { riedelianum } \text { with peel }}
$$

Humidity was determined by the IV3000 infrared light meter (Gehaka, São Paulo, SP, Brazil).

Common-light and polarized images of the starch granules were obtained by the BX51-p optical microscope (Olympus, Tokyo, Japan). The particle size distribution of the starch was directly determined by laser diffraction spectroscopy on the Mastersizer 3000 particle size analyzer (Malvern Panalytical Ltd, Worcestershire, United Kingdom). The average diameter of the granules was measured using the diameter of a sphere of the same volume and the De Brouckere mean diameter, also know as volume-weighted mean diameter [D (4.3)] (Jinapong et al., 2008). The size of the starch granules was determined through the LEO EVO 40 XVP scanning electron microscope (Leo Electron Microscopy Ltd, Cambridge, United Kingdom) at $20 \mathrm{kv}$ and a distance between 7 and $15 \mathrm{~mm}$ (Fernandes et al., 2019).

In order to analyze starch organization, the PANalytical X'PertPROX-ray diffractometer(Malvern Panalytical Ltd, Worcestershire, United Kingdom) was used, with Co radiation and Fe filter according to Hayakawa et al. (1997). Starch crystallinity was quantitatively determined, and the curve connecting the peak bases was plotted on the diffractograms, in addition to a linear base. The area between the curve and the linear base of the diffractogram corresponds to the amorphous area. Relative crystallinity was obtained by the ratio between the crystalline area and the total area shown in the diffractograms, being presented in percentage. The degree of relative crystallinity was estimated using the Microcal Origin, version 8.6, software (OriginLab Corporation, Northampton, MA, 
USA), following the method described by Barbi et al. (2018).

To determine thermal properties, the differential scanning calorimetry (DSC) analysis was performed using the DSC-60A equipment (Shimadzu Corporation, Kyoto, Japan). For this, $4 \mathrm{mg}$ of starch at a dry basis were added to $6 \mu \mathrm{L}$ deionized water, and the samples were kept for 2 hours at room temperature for balance and then placed in a calorimeter and heated to $5^{\circ} \mathrm{C}$ per minute, from 25 to $100^{\circ} \mathrm{C}$ (Leonel et al., 2011). Initial, peak, and conclusion temperatures, as well as the enthalpy variation of the starches, were determined using the TA-60WS thermal analysis workstation (Shimadzu Corporation, Kyoto, Japan). Thermogravimetry (TGA) was measured on the DTG60A/60AH equipment (Shimadzu Corporation, Kyoto, Japan), and the TA-60WS thermal analysis workstation (Shimadzu Corporation, Kyoto, Japan) was used to obtain the values observed on the curves. Viscosity drop (breakdown) and tendency to retrograde (setback) were also assessed.

Paste properties were analyzed with the rapid viscosity analyzer Rapid Visco Analyzer (Newport Scientific Pty Ltd, Warriewood, Australia), in order to determine the viscosity profile of the starches. The values for paste temperature and for maximum, minimum, and final viscosity, as well as for viscosity drop and tendency to retrograde, were obtained according to Silva et al. (2013).

Swelling power and the solubility index were determined by the methodology adapted from Leach et al. (1959), at room temperature and at 60, 70, 80, and $90^{\circ} \mathrm{C}$. Paste clarity was evaluated following the protocol described by Craig (1989) using $1 \mathrm{~g} 100 \mathrm{~mL}^{-1}$ starch suspensions that were gelatinized for $30 \mathrm{~min}$ in a boiling water bath. Transmittance was determined at $650 \mathrm{~nm}$ with the Varian Cary 50 spectrophotometer (Agilent Technologies, Inc., Santa Clara, CA, USA). The samples were stored at $4^{\circ} \mathrm{C}$ for eight days in order to monitor retrogradation, and transmittance was assessed every 24 hours from the first to the eighth day.

Syneresis was obtained by the method proposed by Singh et al. (2004), being considered the amount of water released (\%), according to the equation:

Syneresis $(\%)=\frac{\text { Released liquid }(\mathrm{g})}{\text { Weight of the initial sample }(\mathrm{g})} \times 100$
Means and standard deviations were calculated for the results. For the variables swelling power, paste clarity, and syneresis, data were adjusted to a regression model using the Sisvar software (Ferreira, 2011).

\section{Results and Discussion}

The starch extraction yield of $X$. riedelianum was $7.89 \%$, similar to that of 6.61 to $11.81 \%$ found for arrowroot (Maranta arundinacea L.), a rhizomatous species also known as an unconventional vegetable (Souza et al., 2019). However, these extraction yields are much lower than that of $33.5 \%$, expressed on a dry basis and considered highly efficient, obtained in the Brazilian industry of cassava (Manihot esculenta Crantz) starch (Branco et al., 2020). Therefore, there is a need to evaluate other methods to improve $X$. riedelianum starch extraction efficiency.

The average starch humidity level was $10.57 \pm 0.15 \mathrm{~g}$

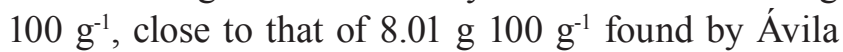
et al. (2012) when also evaluating starch isolated from $X$. riedelianum rhizomes. However, these values are below the limits established by the Brazilian legislation for the good conservation of commercial starches:

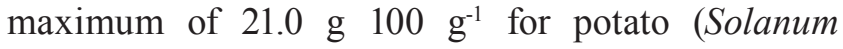
tuberosum L.) and maximum of $18.0 \mathrm{~g} 100 \mathrm{~g}^{-1}$ for cassava (Manihot esculenta Crantz) (Anvisa, 2005).

Birefringent structures called Maltese crosses were identified under light microscopy (Figure 1 A). These structures are characteristic of unfused starch granules and are visible under polarized light due to the high degree of the supramolecular organization of the granules (Xiao et al., 2020). This means that the starch from $X$. riedelianum can be heated to $45^{\circ} \mathrm{C}$ without changing the configuration of the amylose and amylopectin molecules, which could alter the functionality of the starch. This result is also indicative of the wide range of the gelatinization temperature of $X$. riedelianum starch. Therefore, for processes where gelatinization is not desirable, the drying temperature at $45^{\circ} \mathrm{C}$ is safe and, for processes where gelatinization is desired, higher temperatures are required (AlcázarAlay \& Meireles, 2015; Sjõõ \& Nilsson, 2018).

The particle size distribution of $X$. riedelianum starch is polymodal, with three peaks (Figure $2 \mathrm{~A}$ ): the smallest at $1.20 \mu \mathrm{m}$, followed by the main one at $9.25 \mu \mathrm{m}$, and the third at $92.05 \mu \mathrm{m}$. The average volumetric diameter of the particles was expressed 
as the De Brouckere mean diameter [D (4.3)]. For $X$. riedelianum starch, the granule diameter found was of $27.20 \mu \mathrm{m}$, close to that of arrowroot, with most granules with 20-35 $\mu \mathrm{m}$ in diameter (Souza et al., 2019). Granule size is important in numerous applications, influencing the reaction surface and settling speed during industrial processes. Small granules of $2 \mu \mathrm{m}$, for example, can be used as fat substitutes because their size is similar to that of lipid mycelia (Daiuto $\&$ Cereda, 2003). Larger granules, as in the case of those of $X$. riedelianum starch, can be used in the production of biodegradable plastic films, as well as for bakery products (Alcázar-Alay \& Meireles, 2015; Sjõõ \& Nilsson, 2018). Mango (Mangifera indica L.) stick starch, because of its similar characteristics and granule size, can be used to prepare soups, broths, and porridges (Sjõõ \& Nilsson, 2018).

The microscopic analysis showed that the granules presented a smooth surface without superficial porosity and a spherical or semi-spherical shape with an irregular base (Figure $1 \mathrm{~B}$ ), similar to that observed for cassava starch granules by Fernandes et al. (2019). Several compound starch granules were also found, which can be attributed to the presence of other residual compounds, such as proteins and lipids, as reported by Ashogbon \& Akitayo (2012).

The morphology of the starch granules can interfere with the properties of the paste, the solubility of the starch, and the susceptibility of the granules to enzymatic action. The smooth surface of the granule observed in the present study hinders the access of enzymes and delays or hinders enzymatic action, increasing resistance to degradation (Vanier et al., 2019).

Starch is considered resistant when it is partially digested or undigested by the human digestive system, being widely used in the food industry as a dietary fiber, which is desirable for many food products and can be added to formulations. However, the evaluated starch is not the most suitable for the production of simple sugars due to its resistance to degradation by amylolytic enzymes.

Regarding diffraction, the X-ray diffractogram showed a lower intensity peak near $5.6^{\circ}$ in $X$. riedelianum starch, followed by more intense peaks when the $2 \Theta$ angle was near 17, 22, and $26^{\circ}$ (Figure $2 \mathrm{~B}$ ). Therefore, this starch exhibits a B-type diffraction pattern. Most root and tuber starches, such as those from the African arrowroot and different yam species, follow a similar pattern (Hoover, 2001).

The crystallinity index, determined from the total areas and peaks of the X-ray diffractograms, is an important parameter that influences the physical, mechanical, and technological properties of starch. The crystallinity found for $X$. riedelianum starch was of $41.20 \%$, considered high, but within the range suggested by Miranda et al. (2019), between 15 and $45 \%$ for native starches. Higher values like the one
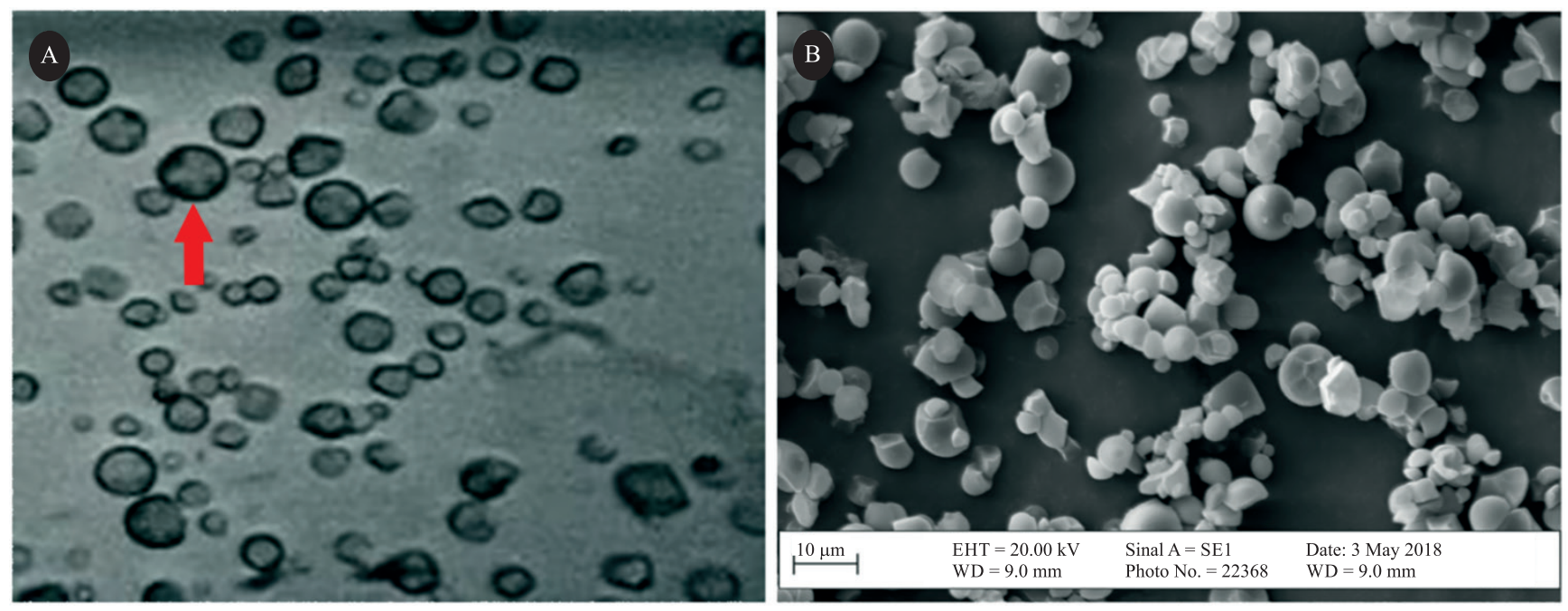

Figure 1. Morphology of Xanthosoma riedelianum starch under optical microscopy using 40 x zoom (A) and micrography of the granules of the starch through scanning electron microscopy (B). 
obtained in the present study imply greater granular stability, which, consequently, reduces the swelling capacity of the granule, making it more resistant to the gelatinization process (Singh et al., 2004). These results confirm that $X$. riedelianum starch is not easily gelatinized. For the food industry, this means higher temperatures and a greater energy expenditure for this process, indicating that chemical gelatinization may be more viable (Alcázar-Alay \& Meireles, 2015; Sjõõ \& Nilsson, 2018).

For gelatinization, the initial temperature was $67.63 \pm 0.44^{\circ} \mathrm{C}$, with a peak at $74.24 \pm 0.50^{\circ} \mathrm{C}$ and conclusion at $80.90 \pm 0.24^{\circ} \mathrm{C}$; the temperature range was $12.61 \pm 0.68^{\circ} \mathrm{C}$ and enthalpy change was $-4.94 \pm 0.078 \mathrm{~J} \mathrm{~g}^{-1}$. If the maximum values of the standard deviations and variation are considered, the gelatinization of starch can occur at temperatures from 67.37 to $94.43^{\circ} \mathrm{C}$; therefore, the obtained average value of $80.90^{\circ} \mathrm{C}$ represents a very high temperature.

Three thermal events of mass loss were observed for TGA/differential thermal analysis (Table 1). The first one corresponds to a mass loss of $9.66 \%$ and was attributed to the evaporation of volatiles, mostly of the water absorbed by the starchy material, which occurred almost at $92.72^{\circ} \mathrm{C}$. The second event is associated with the thermal degradation phase of the major constituents of the starch and was composed by two peaks, beginning at $257.55^{\circ} \mathrm{C}$ and topping out at the degradation maximum of $326.38^{\circ} \mathrm{C}$; the first peak was minor and is related to the loss of amylose, the most linear structure of starch, and the second refers to the degradation of the amylopectin structure, with a total mass loss of $75.74 \%$. Finally, the third event is characterized by a small mass loss of $11.46 \%$ between 434.56 and $485.95^{\circ} \mathrm{C}$ due to the degradation of the carbonaceous material more resistant to temperature. This means industrial processes with temperatures above 92.72 and $257.55^{\circ} \mathrm{C}$ can destroy the structure of amylose and amylopectin, respectively (AlcázarAlay \& Meireles, 2015). When food is baked, for example, the temperature exceeds $250^{\circ} \mathrm{C}$, although it may be slightly lower inside the food. In processes that include pressure increase, the temperature may be slightly lower, causing no damage to amylopectin, but degrading amylose (Sjõõ \& Nilsson, 2018). This can be positive for products in which amylose rearrangement is not desired, i.e., in which starch retrogradation is not the aim.
After the thermogravimetric analysis, it is possible to determine the level of inorganic substances in the
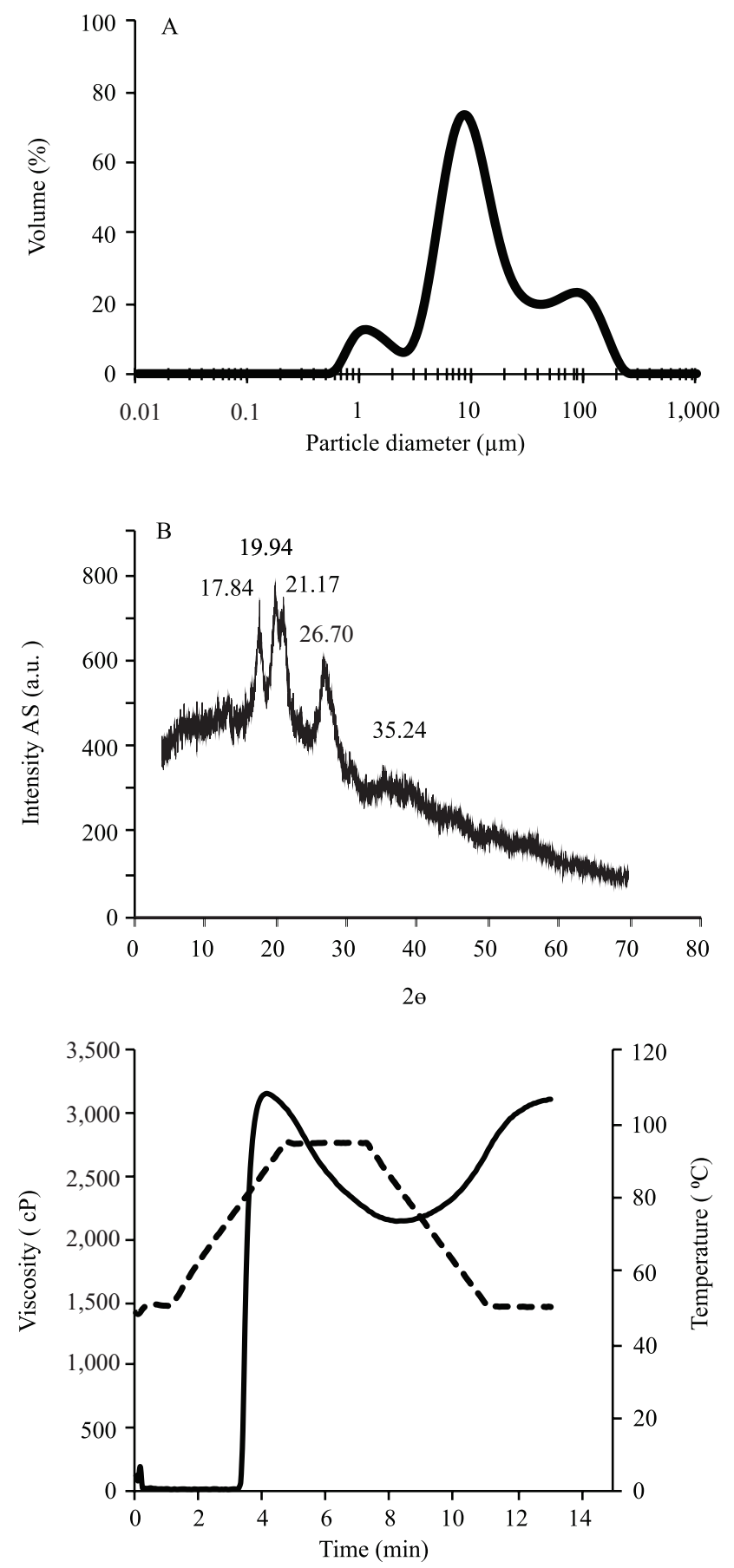

Viscosity

Figure 2. Distribution of the size of the granules of Xanthosoma riedelianum starch (A); X-ray diffractogram of the starch (B); and suspension viscoamylographic profile $(10 \% \mathrm{p} / \mathrm{v})$ of the starch $(\mathrm{C})$. 
studied samples (Sambale et al., 2019). In the present study, the burning residue represented $3.14 \%$ of the total starch mass; this small quantity shows that the starch was well extracted. According to Sjõõ \& Nilsson (2018), starch also contains a certain amount of minerals.

When analyzing paste properties, in the first $3.2 \mathrm{~min}$ (paste time), the starch granules did not change and viscosity was low, of $21 \pm 1.41 \mathrm{cP}$ (Figure $2 \mathrm{C}$ ). Granules started to swell up at $77.9^{\circ} \mathrm{C}$, called paste temperature, indicating that the starch has a high resistance to expansion and rupture, according to Singh et al. (2004). The observed temperature was similar to the one of $82.15^{\circ} \mathrm{C}$ reported by Ávila et al. (2012) for starch from $X$. riedelianum rhizomes. Therefore, the starch from this species needs a relatively high temperature to be gelatinized, requiring a greater energy expenditure and longer cooking time. For corn (Zea mays L.), the gelatinization temperature is, on average, $72^{\circ} \mathrm{C}$ (Sjõõ \& Nilsson, 2018).

After the beginning of paste formation, the granules started to swell, increasing viscosity to $3,263 \pm 7.07$ $\mathrm{cP}$, considered the peak in the heating cycle, reached in $4.13 \mathrm{~min}$, at $88^{\circ} \mathrm{C}$. During the heating period, the viscosity profile indicated some resistance of the bond forces inside the granules, which, when broken, under continuous agitation, caused a decrease of $1,016.5 \pm 6.3$ cP in viscosity, that is, a break. Viscosity breakdown indicates the degree of granule disintegration after swelling and is calculated by the difference between peak and minimum viscosity. The lower the breakdown value, the greater the shear strength and stability of starch in processes involving heating (Andrabi et al., 2016).

Table 1. Thermogravimetry (TGA) and differential thermal analysis (DTA) curves for Xanthosoma riedelianum starch.

\begin{tabular}{lccccc}
\hline Phase & \multicolumn{2}{c}{ TGA } & & \multicolumn{2}{c}{ DTA } \\
\cline { 2 - 3 } \cline { 5 - 6 } & $\begin{array}{c}\text { Mass loss } \\
(\%)\end{array}$ & $\begin{array}{c}\text { Accumulative } \\
\text { loss }(\%)\end{array}$ & $\begin{array}{c}\Delta \mathrm{T} \\
\left({ }^{\circ} \mathrm{C}\right)\end{array}$ & $\begin{array}{c}\mathrm{T}_{\mathrm{p}} \\
\left({ }^{\circ} \mathrm{C}\right)\end{array}$ \\
\hline First & 9.66 & 9.66 & & $44.53-164.92$ & 92.72 \\
Stability & - & 9.66 & & $164.92-257.55$ & - \\
Second & 75.74 & 85.40 & & $257.55-434.56$ & 326.38 \\
Third & 11.46 & 96.86 & & $434.56-485.95$ & 439.35 \\
Residue & 3.14 & - & & $485.95-600.00$ & - \\
\hline
\end{tabular}

${ }^{(1)} \Delta \mathrm{T}$, temperature variation; and $\mathrm{T}_{\mathrm{p}}$, peak temperature.
The retrogradation tendency of $X$. riedelianum starch was of $970 \pm 5 \mathrm{cP}$, lower than that of $1,380 \mathrm{cP}$ observed for cassava and higher than that of $804 \mathrm{cP}$ for potato and of $828 \mathrm{cP}$ for Arracacia xanthorrhiza Bancroft (Shirai et al., 2007). Alcázar-Alay \& Meireles (2015) concluded that the higher the retrogradation tendency, the greater the diameter of the granules due to a higher fragility. In the industries that use starch and also in food industries, the most commonly marketed starches are those from corn, cassava, and potato due to their easy extraction and yield (Souza et al., 2019). In relation to tendency to retrograde, the studied $X$. riedelianum starch has an intermediate behavior to that of the corn and potato starches. When retrogradation is desired, the retrograded corn starch is more easily used in food products, such as chilled desserts; however, for products for which a lower consistency is desired, potato starch is preferred (Sjõõ \& Nilsson, 2018). Therefore, it is assumed that $X$. riedelianum starch can be well used in processes in which retrogradation does not occur so easily, specifically in products for which the lowest viscosity is desired during and after cooling.

The final viscosity of $X$. riedelianum starch was $3,116.5 \pm 19.09 \mathrm{cP}$, being higher than the values of 3,012, 2,448, and 2,520 found for potato, A. xanthorrhiza, and cassava, respectively, by Shirai et al. (2007). Final viscosity is an important parameter for the use of starch in food since it corresponds to the viscosity of a product at a given temperature; in this case, at $50^{\circ} \mathrm{C}$. According to the type of product, a higher or lower viscosity can be desirable; instant soups, for example, must not present a very high final viscosity, which would cause an unpleasant sensation, whereas pie fillings require a higher viscosity to avoid its contents from overflowing during transportation (Garcia et al., 2014). Due to its high levels of viscosity, the starch from $X$. riedelianum would be better indicated for pie fillings, puddings, children's food, and baking products. Daiuto \& Cereda (2003) added that, for the calculation of the desired viscosity, it is necessary to consider the reduction that occurs in viscosity during industrial processing.

The swelling power of $X$. riedelianum starch does not change significantly between 25 and $70^{\circ} \mathrm{C}$, but increases from 70 to $80^{\circ} \mathrm{C}$, continuing up to $90^{\circ} \mathrm{C}(9.80 \pm 0.13 \mathrm{~g})$; although the results suggest a plateau, there were no analyzes at higher temperatures (Figure 3 A). For food

Pesq. agropec. bras., Brasília, v.55, e01765, 2020

DOI: 10.1590/S1678-3921.pab2020.v55.01765 
products, this means that $X$. riedelianum starch must be used in processes that require higher temperatures, above $70^{\circ} \mathrm{C}$, in order for it to absorb more water and become more swollen. Starch swelling is one of the premises for gelatinization to occur (Alcázar-Alay \& Meireles, 2015; Sjõõ \& Nilsson, 2018).

Singh et al. (2004) attributed the low swelling power of starch granules to the presence of several crystals formed by the association of long amylopectin chains, or, to a higher degree of crystallinity, which implicates in a higher stability and, consequently, decreases swelling capacity. In the present study, a high level of crystallinity of $41.20 \%$ was found for $X$. riedelianum starch using the X-ray diffraction analysis.

The average values and standard deviation of the solubility index are presented in a graph (Figure $3 \mathrm{~B}$ ); however, the results did not fit to the proposed mathematical models. The behavior of
$X$. riedelianum starch showed a constant growth of 1.18 to $1.85 \mathrm{~g}$ from room temperature to $70^{\circ} \mathrm{C}$, followed by a drastic decrease to $0.66 \pm 0.22 \mathrm{~g}$ at $80^{\circ} \mathrm{C}$, increasing again at $90^{\circ} \mathrm{C}$. Although the graph is not obeying any mathematical equation, which could predict the behavior of the loss of solids by $X$. riedelianum starch yields as a function of temperature, a good observation and comparison between this graph and the one of swelling power shows that these two forces are complementary or even mirrored. When one value increases, the other decreases, which is the behavior expected for these two forces: the more a granule of common starch absorbs water, the more that granule loses solids (Sjõõ \& Nilsson, 2018).

The obtained results indicated once again that, for the food industry, the processes that involve cooking of $X$. riedelianum starch require higher temperatures, which translates in more time and a greater energy
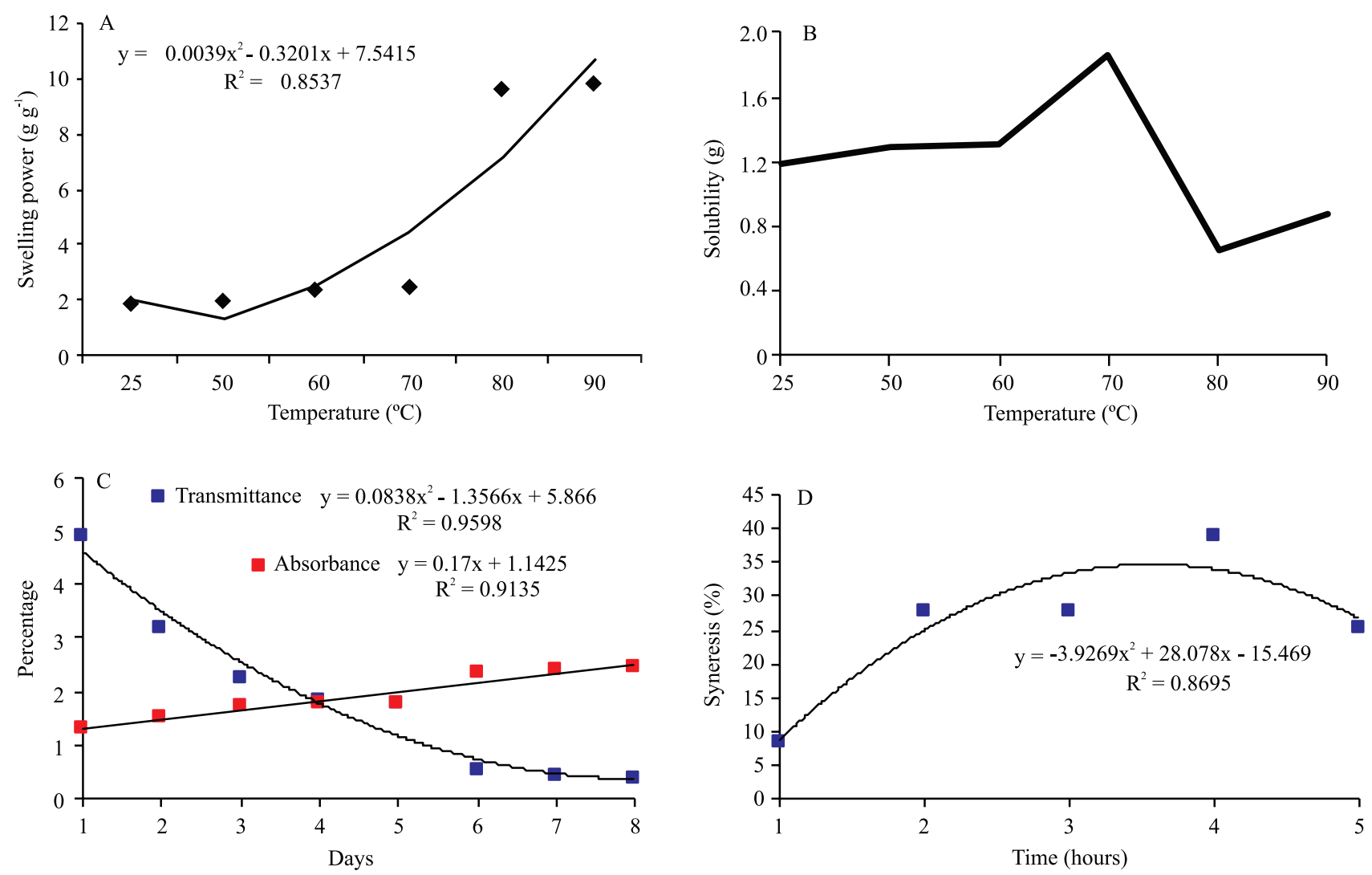

Figure 3. Regression of the swelling power of Xanthosoma riedelianum starch in function of temperature (A); solubility index of the starch as affected by temperature (B); percentage of the absorbance and transmittance of the starch in function of storage time (C); and effect of storage time over the syneresis of the starch (D). 
expenditure when a greater swelling is desired for starch gelatinization, with a consequent increase in the loss of solids by the starch granules. However, when total gelatinization is not desired, $X$. riedelianum starch is a good option because, when added to food formulations, even under a heating process, it will not swell as much and will not reach the gelatinization stage if the processing temperature is below $70-80^{\circ} \mathrm{C}$.

The percentage of absorbance and transmittance determines the clarity of the starch paste: the higher the transmittance, the greater the paste clarity (lower turbidity). On the first day, the transmittance of $X$. riedelianum starch presented the highest average of $4.88 \%$, which decreased over time, reaching an average of $0.36 \%$ on the eighth day. The behavior of absorbance was opposite to that observed for transmittance (Figure 3 C). Hernández-Medina et al. (2008) reported 13.57 and $7.0 \%$ transmittance for arrowroot and taro [Colocasia esculenta (L.) Schott] starch, respectively, whereas Macena et al. (2020) found a value of 2.20\% for avocado (Persea americana Mill.) seed starch.

Starches used as a thickener in pie fillings, in food toppings, or as edible films must be preferentially transparent, while starches used in the bakery, concentrated-drink, and processed-meat sectors may have the characteristics of the analyzed starch, as a clear paste is not necessary to formulate the products (Hernández-Medina et al., 2008; Egharevba, 2020). Therefore, the starch from $X$. riedelianum should be used in foods where translucency is not so important, as in fillings, flans, and puddings, or in the formulation of cakes, breads, and pies, and other bakery products.

The amount of water released by the $X$. riedelianum starch gels during storage increased up to 120 hours, when there was a decrease (Figure $3 \mathrm{D}$ ). For potato starch after 48 hours of storage, Colussi et al. (2018) verified water loss, or syneresis, of $46.10 \%$, which is higher than that of $26.75 \pm 2.71 \%$ found for $X$. riedelianum starch during the same storage period. These different syneresis characteristics can be related to the differences in the quality of the recrystallized amylopectin crystals (Freschi et al., 2014). Water loss is associated with the reorganization of the molecules after cooling and storage, which can affect the functional properties of the starch in terms of viscosity and gel behavior (Charles et al., 2016), and is not considered beneficial to the food industry since it can affect the quality and lifespan of the food.

\section{Conclusions}

1. Xanthosoma riedelianum starch has a low extraction yield.

2. The morphology of $X$. riedelianum starch shows granules without surface porosity, resulting in a low susceptibility to enzymatic action.

3. Xanthosoma riedelianum starch requires high temperature and a longer cooking time to swell and achieve complete gelatinization.

4. Xanthosoma riedelianum starch is indicated for products that require high viscosity such as pie fillings, puddings, children's food, and baking products, and its opaque and viscous paste can also be used to formulate broths.

\section{Acknowledgments}

To Coordenação de Aperfeiçoamento de Pessoal de Nível Superior (Capes), to Conselho Nacional de Desenvolvimento Científico e Tecnológico (CNPq), and to Fundação de Amparo à Pesquisa do Estado de Minas Gerais (Fapemig), for scholarships and financial support.

\section{References}

ALCÁZAR-ALAY, S.C.; MEIRELES, M.A.A. Physicochemical properties, modifications and applications of starches from different botanical sources. Food Science and Technology, v.35, p.215-236, 2015. DOI: https://doi.org/10.1590/1678-457X.6749.

ANDRABI, S.N.; WANI, I.A.; GANI, A.; HAMDANI, A.M.; MASOODI, F.A. Comparative study of physico-chemical and functional properties of starch extracted from two kidney bean (Phaseolus vulgaris L.) and green gram cultivars (Vigna radiata L.) grown in India. Starch, v.68, p.416-426, 2016. DOI: https://doi.org/10.1002/star.201500217.

ANVISA. Agência Nacional de Vigilância Sanitária. Resolução RDC $n^{\circ} 263$, de 22 de setembro de 2005. [Aprova o regulamento técnico para produtos de cereais, amidos, farinhas e farelos]. Diário Oficial da União, 23 set. 2005. Seção1, p.368-369.

ASHOGBON, A.O.; AKINTAYO, E.T. Morphological, functional and pasting properties of starches separated from rice cultivars grown in Nigeria. International Food Research Journal, v.19, p.665-671, 2012.

ÁVILA, R. de; ASCHERI, D.P.R.; ASCHERI, J.L.R. Caracterização dos rizomas filhos e da fécula do mangarito (Xanthosoma mafaffa Schott) e elaboração de filmes biodegradáveis. Boletim Centro de Pesquisa de Processamento de Alimentos, v.30, p.35-52, 2012. DOI: https://doi.org/10.5380/ cep.v30i1.28581. 
BARBI, R.C.T.; TEIXEIRA, G.L.; HORNUNG, P.S.; ÁVILA, S.; HOFFMANN-RIBANI, R. Eriobotrya japonica seed as a new source of starch: assessment of phenolic compounds, antioxidant activity, thermal, rheological and morphological properties. Food Hydrocolloids, v.77, p.646-658, 2018. DOI: https://doi.org/10.1016/j.foodhyd.2017.11.006.

BRANCO, F.P.; CEREDA, M.P.; NAKA, M.H. Comparison of arrowroot (Maranta arundinacea) and cassava starch extraction in separation, concentration, and purification using a rotating sieve under water. Engenharia Agrícola, v.40, p.90-95, 2020. DOI: https://doi.org/10.1590/1809-4430-eng.agric.v40n1p90-95/2020.

CHARLES, A.L.; CATO, K.; HUANG, T.-C; CHANG, Y.-H.; CIOU, J.-Y.; CHANG, J.-S.; LIN, H.-H. Functional properties of arrowroot starch in cassava and sweet potato composite starches. Food Hydrocolloids, v.53, p.187-191, 2016. DOI: https://doi.org/10.1016/j.foodhyd.2015.01.024.

COLUSSI, R.; KAUR, L.; ZAVAREZE, E. da R.; DIAS, A.R.G.; STEWART, R.B.; SINGH, J. High pressure processing and retrogradation of potato starch: influence on functional properties and gastro-small intestinal digestion in vitro. Food Hydrocolloids, v.75, p.131-137, 2018. DOI: https://doi.org/10.1016/j.foodhyd.2017.09.004.

CRAIG, S.A.S.; MANINGAT, C.C.; SEIB, P.A.; HOSENEY, R.C. Starch paste clarity. Cereal Chemistry, v.66, p.173-182, 1989.

DAIUTO, E.R.; CEREDA, M.P. Amido como suporte na desidratação por atomização e em microencapsulamento. In: CEREDA, M.P.; VILPOUX, O.F. (Coord.). Tecnologia, usos e potencialidades de tuberosas amiláceas latino americanas. São Paulo: Fundação Cargill, 2003. p.449-475. (Culturas de Tuberosas Amiláceas Latino Amaricanas, 3).

EGHAREVBA, H.O. Chemical properties of starch. In: EGHAREVBA, H.O. Chemical properties of starch and its application in the food industry. Rijeka: IntechOpen, 2020. DOI: https://doi.org/10.5772/intechopen.87777.

FERNANDES, D. de S.; SANTOS, T.P.R. dos; FERNANDES, A.M.; LEONEL, M. Harvest time optimization leads to the production of native cassava starches with different properties. International Journal of Biological Macromolecules, v.132, p.710-721, 2019. DOI: https://doi.org/10.1016/j. ijbiomac.2019.03.245.

FERREIRA, D.F. Sisvar: a computer statistical analysis system. Ciência e Agrotecnologia, v.35, p.1039-1042, 2011. DOI: https://doi.org/10.1590/S1413-70542011000600001.

FRESCHI, J.; DORAN, L.; MALUMBA, P.; BLECKER, C. Impact of freezing and thawing processes on wheat and potato starch gel syneresis. Starch, v.66, p.208-215, 2014. DOI: https://doi.org/10.1002/star.201200294.

GARCIA, L.E.; LEONEL, M.; CARMO, E.L. do; PÁDUA, J.G. de. Batata cv Pirassu como matéria-prima industrial. Energia na Agricultura, v.29, p.220-227, 2014. DOI: https://doi.org/10.17224/ EnergAgric.2014v29n3p220-227.

HAYAKAWA, K.; TANAKA, K.; NAKAMURA, T.; ENDO, S.; HOSHINO, T. Quality characteristics of waxy hexaploid wheat (Triticum aestivum L.): properties of starch gelatinization and retrogradation. Cereal Chemistry, v.74, p.576-580, 1997. DOI: https://doi.org/10.1094/CCHEM.1997.74.5.576.

HERNÁNDEZ-MEDINA, M.; TURRUCO-UCO, J.G.; CHELGUERRERO, L.; BETANCUR-ANCONA, D. Caracterización fisicoquímica de almidones de tubérculos cultivados en Yucatán, México. Ciência e Tecnologia de Alimentos, v.28, p.718-726. 2008. DOI: https://doi.org/10.1590/S0101-20612008000300031.

HOOVER, R. Composition, molecular structure, and physicochemical properties of tuber and root starches: a review. Carbohydrate Polymers, v.45, p.253-267, 2001. DOI: https://doi.org/10.1016/S0144-8617(00)00260-5.

JINAPONG，N.; SUPHANTHARIKA， M.; JAMMONG，P. Production of instant soymilk powders by ultrafiltration, spray drying and fluidized bed agglomeration. Journal of Food Engineering, v.84, p.194-205, 2008. DOI: https://doi.org/10.1016/j. jfoodeng.2007.04.032.

LEACH, H.W.; MCCOWEN, L.D.; SCHOCH, T.J. Structure of the starch granule. I. Swelling and solubility patterns of various starches. Cereal Chemistry, v.36, p.534-544, 1959.

LEONEL, M.; CARMO, E.L. do; LEONEL, S.; FRANCO, C.M.L.; CAMPANHA, R.B. Extração e caracterização do amido de diferentes genótipos de bananeira. Revista Brasileira de Fruticultura, v.33, p.599-605, 2011. Número especial. DOI: https://doi.org/10.1590/S0100-29452011000500082.

LEWICKA, K.; SIEMION, P.; KURCOK, P. Chemical modifications of starch: microwave effect. International Journal of Polymer Science, v.2015, art.867697, 2015. DOI: https://doi.org/10.1155/2015/867697.

MACENA, J.F.F.; SOUZA, J.C.A. de; CAMILLOTO, G.P.; CRUZ, R.S. Physico-chemical, morphological and technological properties of the avocado (Persea americana Mill. cv. Hass) seed starch. Ciência e Agrotecnologia, v.44, e001420, 2020. DOI: https://doi.org/10.1590/1413-7054202044001420.

MADEIRA, N.R.; BOTREL, N.; AMARO, G.B.; MELO, R.A. de C. e. Mangarito: sabor de tradição. Horticultura Brasileira, v.33, p.409, 2015. DOI: https://doi.org/10.1590/S0102053620150000300023.

MIRANDA, J.A.T. de; CARVALHO, L.M.J. de; VIEIRA, A.C. de M.; CASTRO, I.M. de. Scanning electron microscopy and crystallinity of starches granules from cowpea, black and carioca beans in raw and cooked forms. Food Science and Technology, v.39, p.718-724, 2019. Suppl.2. DOI: https://doi.org/10.1590/ fst.30718.

SAMBALE, A.; KURKOWSKI, M.; STOMMEL, M. Determination of moisture gradients in polyamide 6 using StepScan DSC. Thermochimica Acta, v.672, p.150-156, 2019. DOI: https://doi.org/10.1016/j.tca.2018.12.011.

SHIRAI, M.A.; HAAS, Â.; FERREIRA, G.F.; MATSUGUMA, L.S.; FRANCO, C.M.L; DEMIATE, I.M. Características físicoquímicas e utilização em alimentos de amidos modificados por tratamento oxidativo. Ciência e Tecnologia de Alimentos, v.27, p.239-247, 2007. DOI: https://doi.org/10.1590/S010120612007000200005 . 
SILVA, M.C. da; ASCHERI, D.P.R.; CARVALHO, C.W.P. de; GALDEANO, M.C.; ANDRADE, C.T. de. Characterization of cassava starch processed in an internal mixer. Polímeros, v.23, p.725-732, 2013. DOI: https://doi.org/10.4322/polimeros.2014.007.

SINGH, N.; SANDHU, K.S.; KAUR, M. Characterization of starches separated from Indian chickpea (Cicer arietinum L.) cultivars. Journal of Food Engineering, v.63, p.441-449, 2004. DOI: https://doi.org/10.1016/j.jfoodeng.2003.09.003.

SJÕÕ, M.; NILSSON, L. (Ed.). Starch in food: structure, function and applications. $2^{\text {nd }}$ ed. [S.1.]: Salt Woodhead, 2018. 916p.

SOUZA, D.C. de; SILVA, L.F.L.; RESENDE, L.V.; COSTA, P.A.; GUERRA, T.S.; GONÇALVES, W.M. Influence of irrigation, planting density and vegetative propagation on yield of rhizomes of arrowroot starch. Revista de Ciências Agrárias, v.41, p.683691, 2018. DOI: https://doi.org/10.19084/RCA18015.

SOUZA, D.C. de; SILVA, R. de J.; GUERRA, T.S.; SILVA, L.F.L. e; RESENDE, L.V.; PEREIRA, J. Characterization of arrowroot starch in different agronomic managements. Revista
Ceres, v.66, p.323-332, 2019. DOI: https://doi.org/10.1590/0034$737 \times 201966050001$.

VANIER, N.L.; OLIVEIRA, J.P. de; BRUNI, G.P.; EL HALAL, S.L.M.; VILLANOVA, F.A.; ZAVAREZE, E. da R.; DIAS, A.R.G.; BASSINELLO, P.Z. Characteristics of starch from different bean genotypes and its effect on biodegradable films. Journal of the Science of Food and Agriculture, v.99, p.12071214, 2019. DOI: https://doi.org/10.1002/jsfa.9292.

WATERSCHOOT, J.; GOMAND, S.V.; FIERENS, E.; DELCOUR, J.A. Production, structure, physicochemical and functional properties of maize, cassava, wheat, potato and rice starches. Starch, v.67, p14-29, 2015. DOI: https://doi.org/10.1002/ star.201300238.

XIAO, H.; WANG, S.; XU, W.; YIN, Y.; XU, D.; ZHANG, L.; LIU, G.-Q.; LUO, F.; SUN, S.; LIN, Q.; XU, B. The study on starch granules by using darkfield and polarized light microscopy. Journal of Food Composition and Analysis, v.92, art.103576, 2020. DOI: https://doi.org/10.1016/j.jfca.2020.103576. 